DOI 10.18551/rjoas.2019-06.17

\title{
ANALYSIS OF SMALL-SCALE FISH HANDLING DEVELOPMENT IN REMBANG WATERS
}

\author{
Nurnaini Rudiro*, Wijayanto Dian, Fitri Aristi Dian Purnama \\ Faculty of Fisheries and Marine Science, University of Diponegoro, Indonesia \\ *E-mail: rudiro bbppi@yahoo.com
}

\begin{abstract}
Fishing vessels in Rembang Regency, Indonesia, are mostly small-scale ones with a size of less than $10 \mathrm{GT}$. Small size fishing vessels use ice blocks as a chilling medium during fish handling in the sea. Handling the catch using ice blocks appears to be nonoptimal, so improvement in technology is needed. The aim of the study was to determine alternative fish handling suitable for small-scale fishing management in Rembang Regency. The research employed a descriptive method using the AHP (Analytical Hierarchy Process) analysis related to technological feasibility. The research results of AHP analysis reveal that the weight value of handling fish without using ice is 0.1098 , using ice blocks is 0.2711 , and using RSW (Refrigerated Sea Water) is 0.6192. Small-scale fish management in Rembang Regency prefers using RSW for handling the catch.
\end{abstract}

\section{KEY WORDS}

Fishing, small-scale fish handling, Rembang waters, Indonesia.

Most of the fishermen's fishing vessels in Rembang Regency, Indonesia, are smallscale ones with a size of less than 10 GT. Small size fishing vessels usually use ice blocks as a chilling medium for handling fish in the sea. Improper use of ice blocks will cause spoilage to the catch. Spoiled fish can reduce fish selling since they will be undesirable to customers. Riyadi (2016) asserted that the research result of conventional fish catch handling by using ice blocks was not optimal; thus, there must be efforts made to improve fish handling through renewable technology.

RSW (Refrigerated Sea Water) chiller is a renewable technology to handle fish catch using refrigerated seawater as a chilling medium through a refrigeration machine. The RSW system has several advantages: (a) It can prolong fish freshness/it has longer storage time; (b) it prevents physical damage because fish are not piled up and pressed by other fish or ice blocks; (c) the temperature will drop rapidly because all fish are in contact with the coolant (rapid cooling process); (d) Fish handling procedures are easier and faster, both in loading/unloading so it saves time and labor; and (e) the quality of the catch is physically better (Riyadi, 2016). This study aims to determine alternative fish handling suitable for small-scale fishing management in Rembang Regency.

\section{METHODS OF RESEARCH}

This research was conducted in Plawangan Village, Kragan District, Rembang Regency, regency in Jawa Tengah (Central Java) Province of Indonesia. The location is located at $111^{\circ} 00^{\prime}-111^{\circ} 30^{\prime}$ East Longitude and $06^{\circ} 30^{\prime}-07^{\circ} 00^{\prime}$ South Latitude (figure 1). The study employed an interview/questionnaire and observation methods. The questionnaires were distributed to 10 respondents, who were the staff of Fisheries and Marine Service of Central Java Province, lecturers, practitioners, and fishermen.

Development policy analysis is conducted to determine the appropriate policy alternatives for fish handling suitable for small-scale fishing management in Rembang Regency. It utilizes the Analytical Hierarchy Process (AHP) (Saaty, 2008). The first step is compiling the hierarchies, placing priority factors through pairwise comparisons (table 1), and conducting normalization. In the analysis, the calculation of priority vectors and their number are intended to determine the importance of these priority factors in small-scale fish handling. 

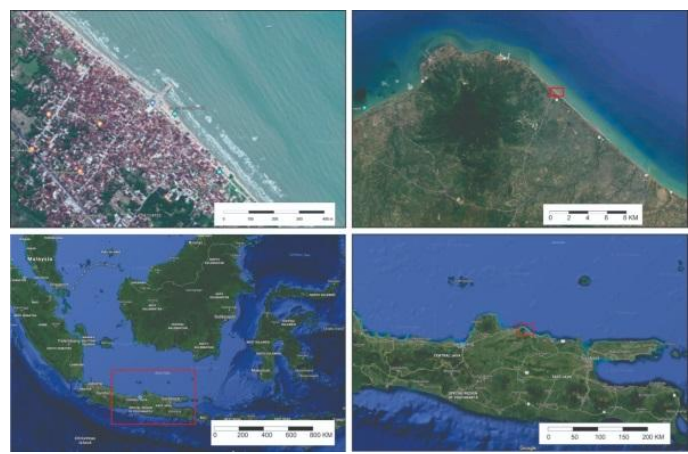

Figure 1 - The Research Location Map

The pairwise comparison matrix values are filled with numbers that describe a factor's level of importance compared to the others within a range of 1-9 (table 2).

Table 1 - The Pairwise Comparison

\begin{tabular}{cccc}
\hline & $\mathrm{C}_{1}$ & $\mathrm{C}_{2}$ & $\mathrm{Cn}$ \\
\hline $\mathrm{C}_{1}$ & 1 & $\mathrm{a} 12$ & $\mathrm{a} 1 \mathrm{n}$ \\
$\mathrm{C}_{2}$ & $1 / \mathrm{a} 12$ & 1 & \\
\hline Total & $\Sigma \mathrm{a}_{11}$-an1 & & $\sum \mathrm{a}_{1} \mathrm{n}$-aij \\
\hline
\end{tabular}

Note: $C_{1} \ldots C n$ is a criterion at a certain level of the criteria to be compared that reflects the importance value of $C_{1}$ to $C j ; a_{12} \ldots$ aij is a comparison value based on the pairwise comparison scale table.

Table 2 - The Factor's Importance Value

\begin{tabular}{ll}
\hline Level & Definition \\
\hline 1 & The two factors are equally important \\
3 & One factor is slightly more important than the others \\
5 & One factor is more important than the others \\
9 & One factor is obviously more important than the others \\
$2,4,6,8$ & One factor is absolutely more important than the others \\
$1 / 1$ s/d $1 / 9$ & Uncertainty between two adjacent values \\
\hline
\end{tabular}

Source: Saaty, 2008.

\section{RESULTS AND DISCUSSION}

The fish handling for small-scale fishing vessels is expected to maintain the quality of the catch, which will increase fish selling prices and the income of small-scale fishermen; ultimately, it can improve the welfare of small-scale fishermen. Supartono, et al. (2011) in Kusumayanti, (2018), stated that economists generally measure welfare level by looking at economic variations, particularly the income levels. Winardi, (1996) in Kusumayanti, (2018), pointed out that the income or profit obtained is expected to meet the life needs of a worker. Todaro, (2004) in Kusumayanti, (2018), asserted that the level of income reflects economic growth that must be achieved in a good economy, which can provide welfare for all residents in the country or region.

Based on the consultations with practitioners and academics, several important factors were identified in small-scale fish handling. They are the space requirement, operational ease, the fish quality and selling price resulting from the fish handling. Supporting this, Masyahoro (2006) presented that the determinants of success in fisheries business are technology, facilities, infrastructure, market potential, product quality and price. The space requirement (facilities and infrastructure) in fish handling is one of the factors that must be considered because inappropriate space for fish handling will interfere with fishing activities. Operational ease in handling after fishing is also essential as easy-to-operate technology will save time and skills. Additionally, the other important factors are the fish quality and selling 
price. Masyahoro (2006) argued that the fish quality and price are directly related to the supply and sale value of the catch, which affects the total income and profits.

There are three alternatives to small-scale fish handling: fish handling without using chillers (ice blocks), using ice block for chilling, and using RSW for chilling. Based on AHP analysis, the order of priority in small-scale fish handling is obtained from the highest to the lowest weight.

Based on the survey results obtained from all relevant stakeholders, there are several factors that must be considered in fish handling. Table 3 presents the pairwise comparison of each factor and weight value.

The fish selling price of fish handling with a weight value of 0.37 is the most important factor in small-scale fish handling since it is the main factor in supporting fishermen's income.

Table 3 - Pairwise Comparison Factors and Weight

\begin{tabular}{cccccc}
\hline & SR & OE & FQ & FSP & Weight \\
\hline NFP & 1.00 & 0.84 & 0.38 & 0.21 & 0.12 \\
OE & 1.19 & 1.00 & 0.61 & 0.80 & 0.20 \\
FQ & 2.60 & 1.64 & 1.00 & 0.86 & 0.31 \\
FSP & 4.82 & 1.25 & 1.16 & 1.00 & 0.37 \\
\hline
\end{tabular}

Note: $S R$ - space requirement; $O E$ - operational ease; $F Q$ - fish quality; FSP - fish selling price.

The fish quality from fish handling with a weight value of 0.31 is placed as the second factor of small-scale fish handling. The good fish quality will have an effect on the price level. Masyahoro (2006) asserted that the fish quality and price are directly related to the supply and selling value of the catch, which will certainly affect the value of the company's income and profits.

The operational ease of handling fish occupies the third factor with a weight of 0.20 , after fish price and quality. By utilizing a new handling medium, fishermen will require the skill to operate it. If it is easy to operate, it will be very helpful for the fishermen.

The space requirement of fish handling is placed next with a weight value of 0.12 . Chilling medium requires space for handling fish on board, especially one that uses renewable technology such as RSW.

There are three alternatives to small-scale fish handling: fish handling without using chillers (ice blocks), using ice block for chilling, and using RSW for chilling.

Table 4 - The Weight of Handling Alternatives Based on Handling Factors

\begin{tabular}{|c|c|c|c|c|}
\hline Factor & Weight & Without ice blocks & RSW & With ice blocks \\
\hline SR & 0.12 & 0.10 & 0.66 & 0.24 \\
\hline OE & 0.20 & 0.26 & 0.44 & 0.31 \\
\hline FQ & 0.31 & 0.07 & 0.65 & 0.28 \\
\hline FSP & 0.37 & 0.07 & 0.68 & 0.25 \\
\hline \multicolumn{2}{|l}{ Total } & 0.11 & 0.62 & 0.27 \\
\hline
\end{tabular}

Note: SR - space requirement; $O E$ - operational ease; $F Q$ - fish quality; FSP - fish selling price.

The effects of small-scale fish handling alternatives on the space requirement priority are (table 4):

- The handling alternative of using RSW chiller affects the space requirement priority as much as 0.66; this indicates that the RSW chiller highly needs a space compared to using ice blocks or without using any chiller. Since RSW chiller has a large system and space requirement, any improper installation will interfere with fishermen's activities;

- The handling alternative of using ice blocks affects the space requirement priority as much as 0.24 ; this means that using ice blocks as chiller will require more space than without using them, as they need adequate space for storage; 
- The handling alternative of utilizing no chiller affects the space requirement priority as much as 0.10 ; in other words, it is the lowest value of space requirement. Naturally, it does not need a space for storage as it does not use ice blocks.

Furthermore, the effects of small-scale fish handling alternatives on the operational ease priority are (table 4):

- The handling alternative using RSW chiller affects the priority of operational ease as much as 0.44 . This chilling medium does not require a large amount of energy for its operations, because it only requires sea water; the use of ice blocks, on the other hand, requires energy for the process of moving ice blocks from the land to the vessel. According to Riyadi (2016), the fish handling procedure of loading and unloading is easier and faster; thus, it saves time and effort;

- The handling alternative of using ice block chiller affects the priority of operational ease as much as 0.31 ;

- The handling alternative without using any chiller affects the priority of operational ease as much as 0.26 .

The effects of small-scale fish handling alternatives on the fish quality priority resulting from chilling are (table 4):

- The handling alternative of using RSW chiller affects the fish quality priority as much as 0.65. According to Riyadi (2016) and Budiarto (2013), the fish stay fresh longer, they are not physically damaged and has better quality;

- The handling alternative of using ice blocks affects the fish quality priority as much as 0.28 ;

- The handling alternative of utilizing no chiller affects the fish quality priority as much as 0.07 . Riyadi (2016) and Budiarto (2013) asserted that the fish quality will decrease by $50 \%$ after they are caught.

The effects of small-scale fish handling alternatives on the fish selling price priority resulting from chilling are (table 4):

- The handling alternative of using RSW chiller affects the fish selling price priority as much as 0.68 . Fish selling prices are affected by the fish quality; fish with good quality will increase the selling price, while fish with poor quality will decrease the selling prices. The RSW chilling can maintain the fish quality, so this makes the fish selling price better than others;

- The handling alternative of using ice blocks affects the fish selling price priority as much as 0.25 ;

- The handling alternative without using any chiller affects the fish selling price priority as much as 0.07 .

In sequence, the total number of weights of the three alternatives are: (1) without using ice blocks is 0.11 ; (2) using ice blocks is 0.27 ; (3) using RSW is 0.62 . This reveals that fish handling using RSW medium is preferred for small-scale fish handling. Taking the weight value into account, the major factor is the fish selling price as it has a direct effect on fishermen's income. The second factor is the space requirement since using the RSW technology requires an appropriate space that does not interfere with the fishing operation. The third factor is fish quality, and the last one is operational ease.

\section{CONCLUSION}

The alternative fish handling selected for small-scale fishing management in Rembang Regency is to utilize RSW renewable technology. In sequence, this alternative takes the fish selling price, the space requirement, the fish quality, and operational ease into account.

\section{ACKNOWLEDGMENTS}

This is a contribution paper of the Engineering Functional Research funded by the Center for Fishing, Ministry of Maritime Affairs and Fisheries according to the Decree 
Number: $05 / \mathrm{BBPI} / \mathrm{Kp} .440 / 1 / 2016$, January $4^{\text {th }}, 2016$. The author would like to express gratitude to the Functional Engineers colleagues The Center for Fishing, and to respondents assisting in the research activities.

\section{REFERENCES}

1. BBPI. 2014. Laporan Kegiatan Uji Coba Small Capacity Portable Refrigerated Sea Water System untuk Kapal Penangkap Ikan Skala Kecil. Research Report. Semarang: Balai Besar Penangkapan Ikan, Direktorat Perikanan Tangkap - KKP.

2. BBPI. 2015. Laporan Kegiatan Uji Operasional Small Capacity Portable Refrigerated Sea Water System untuk Kapal Penangkap Ikan Skala Kecil. Research Report. Semarang: Balai Besar Penangkapan Ikan, Direktorat Perikanan Tangkap - KKP.

3. Budiarto, U., Kiryanto \& H. Firmansyah. 2013. Rancang Bangun Sistem Refrigerated Sea Water (RSW) untuk Kapal Nelayan Tradisional. Jurnal Kapal. 10(1):48-57.

4. DKP Kabupaten Rembang. 2016. Laporan Tahunan Bidang Kelautan and Perikanan Kabupaten Rembang Tahun 2015. Research Report. Rembang: Dinas Kelautan and Perikanan Kabupaten Rembang, Pemerintah Kabupaten Rembang, Jawa Tengah.

5. Ibrahim R.. \& Dewi, E. N. 2008. Pendinginan Ikan Bandeng (Chanos chanos Forsk) dengan Es Air Laut Serpihan (Sea Water Flake Ice) and Analisa Mutunya. Jurnal Saintek Perikanan, 3(2):27-32

6. Ilyas, S,. 1988. Teknologi Refrigerasi Hasil Perikanan, Teknik Pendinginan Ikan, $1^{\text {st }}$ Edition. Jakarta: Badan Penelitian and Pengembangan Pertanian, Pusat Penelitian and Pengembangan Perikanan.

7. Ilyas, S,. 1993. Teknologi Refrigerasi Hasil Perikanan, Teknologi Refrigerasi Hasil Perikanan, $2^{\text {nd }}$ Edition. Jakarta: Badan Penelitian and Pengembangan Pertanian, Pusat Penelitian and Pengembangan Perikanan.

8. Junianto. 2003. Teknik Penanganan Ikan. Jakarta: Penebar Swadaya.

9. Kurniawan, M. A. \& Baheramsyah. 2014. Desain Sistem Spray (RSW) Refrigerated Sea Water untuk Ruang Palka Kapal Purse Seine 40 GT. Jurnal Teknik Pomits. 3(1):124-128.

10. Kusumayanti, N. M. D,. 2018. Analisis Faktor-faktor yang Mempengaruhi Kesejahteraan Nelayan di Kab. Jembrana. E-Jurnal Ekonomi and Bisnis Universitas Udayana. $7(11): 2437-2466$.

11. Masyahoro, A,. 2006. Analisis Kebijakan Pengembangan Perikanan Purse Seine dengan Metode AHP di Perairan Kab. Parigi Moutong. J. Agroland. 13(3):275-281.

12. Nugraheni, H,. 2013. Analisi Pengelolaan Pelabuhan Perikanan Pantai Tasikagung Kabupaten Rembang untuk Peningkatan Produksi Perikanan Tangkap. Journal of Fisheries Resources Utilization Management and Technology. 2(1):85-94.

13. Nugroho, T. A., Kiryanto, \& Berlian, A. A. 2016. Kajian Eksperimen Penggunaan Media Pendingin Ikan berupa Es Basah and ice Pack sebagai Upaya peningkatan Performance Tempat Penyimpanan Ikan Hasil Tangkapan Nelayan. Jurnal Teknik Perkapalan. 4(4):889-898.

14. Pangabean, M. A. 2016. Studi Peran Subsektor Perikanan dalam Pengembangan Wilayah di Kota Sibolga. J. II. Tan. Lingk. 18(1):49-55.

15. Poernomo, $\mathrm{H},$. 2015. Analisis Karakteristik Unjuk Kerja Sistem Pendingin yang Menggunakan Freon R22 Berdasar pada Variasi Putaran Kipas Pendingin Kondensor. Kapal. 12(1):1-8.

16. Rahardjo, O. B. 2015. Uji Coba SCP-RSW Kapasitas Kecil untuk Kapal Penangkap Ikan Skala Kecil. Arioma. $32: 56-68$

17. Riyadi, M. 2016. Analisa Teknis and Ekonomis Penggunaan Sistem Pendingin Refrigerated Sea Water (RSW) pada Kapal Ikan Tradisional. Jurnal Teknik Perkapalan. $4(1): 101-112$.

18. Saaty, T., 2008. Decision Making With the Analytic Hierarchy Process. Int. J. Services Sciences. 1(1):83-98.

19. Setyoko, B., S., Darmanto, \& Rahmat. 2007. Analisa Mesin Pendingin pada Kapal Ikan (Refrigerated Sea Water). Teknik. 28(3):245-250. 